Tersedia online di: http://ejournal-balitbang.kkp.go.id/index.php/ma

\title{
KERAGAAN BIOREPRODUKSI TIGA GENERASI IKAN TAMBAKAN (Helostoma temminckii Cuvier, 1829)
}

\author{
Wahyulia Cahyanti”, Jojo Subagja, Kusdiarti, Deni Irawan, dan Otong Zenal Arifin \\ Balai Riset Perikanan Budidaya Air Tawar dan Penyuluhan Perikanan \\ Jl. Sempur No. 1, Bogor
}

(Naskah diterima: 25 September 2020; Revisi final: 22 April 2021; Disetujui publikasi: 23 April 2021)

\begin{abstract}
ABSTRAK
Ikan tambakan merupakan ikan lokal yang potensial menjadi ikan budidaya. Salah satu proses penting dalam budidaya adalah aspek reproduksi. Penelitian untuk mengetahui karakteristik bioreproduksi tiga generasi ikan tambakan hasil kegiatan domes'tikasi di Balai Riset Perikanan Budidaya Air Tawar dan Penyuluhan Perikanan, Bogor. Pengujian dilakukan untuk mengetahui posisi gonad, fekunditas, derajat pembuahan, dan derajat penetasan ikan tambakan generasi yang berbeda. Hasil yang diperoleh menunjukkan posisi gonad vertikal mengarah ke tulang belakang, di bagian ujung melengkung ke arah depan dan gonad berada di belakang urogenital. Fekunditas telur/gram bobot ikan yang dihasilkan tidak berbeda antar generasi dengan jumlah berkisar antara $76 \pm 13$ sampai $83 \pm 14$ butir. Persentase telur terbuahi dan telur menetas antar generasi juga tidak berbeda, masing-masing berkisar antara antara 70,6 \pm 16,05 sampai $92,9 \pm 10,88 \%$ dan $51,3 \pm 16,64$ sampai $74,3 \pm 10,32 \%$ Jumlah larva yang dihasilkan juga tidak berbeda nyata antar generasi, berurutan dari yang kecil ke besar G-0 (38,7 $\pm 10,72$ butir/g bobot ikan), G-1 (45,3 \pm 5,20 butir/g bobot ikan), dan G-2 (55,7 \pm 7,75 butir/g bobot ikan). Program domestikasi ikan tambakan tidak mempengaruhi karakter reproduksi ikan antar generasi. Keragaman karakter reproduksi antar generasi masih tinggi. Pembentukan generasi selanjutnya perlu dipertahankan, sehingga dapat digunakan sebagai ikan budidaya baru.
\end{abstract}

\section{KATA KUNCl: bioreproduksi; fekunditas; indeks kematangan gonad; ikan tambakan \\ ABSTRACT: Bioreproductive characteristics of three generations of kissing gourami fish. By: Wahyulia Cahyanti, Jojo Subagja, Kusdiarti, Deni Irawan, and Otong Zenal Arifin}

Kissing gourami is an Indonesian local fish species that has the potential to be developed as a farmed fish. However, the current domestication stage of the fish still requires further information regarding its bio reproduction. The research on determining the bioreproductive characteristics of three generations of kissing gourami has been carried out at the Research Institute of Freshwater Aquaculture and Fisheries Extensions, Bogor. This research aimed to determine the gonad position, gonad maturity index, and fecundity between the kissing gourami generations. The results showed that the gonads were positioned vertically towards the backbone, curved ends towards the front and located behind the urogenital. The fecundity of produced eggs/gram body weight of fish did not differ between generations and ranged between $76 \pm 13-83 \pm 14$ eggs. The percentages of fertilized eggs and hatched eggs between generations did not differ and ranged between $70.6 \pm 16.05-92.9 \pm 10.88 \%$ and $51.3 \pm 16.64-74.3 \pm 10.32 \%$ respectively. The number of produced larvae was also not significantly different between generations where G-0 has the lowest number (38.7 \pm 10.72 eggs/g fish weight), followed by G-1 (45.3 \pm 5.20 eggs/g fish weight) and G-2 has the highest number of produced larvae (55.7 \pm 7.75 eggs/g fish weight). The aquaculture domestication program does not affect the reproductive character of fish between generations. The diversity of reproductive characters between generations is still high. The formation of the next generation needs to be maintained, so that it can be used as a new cultured fish.

KEYWORDS: bioreproduction; fecundity; gonad maturity index; kissing gourami

\footnotetext{
\# Korespondensi: Balai Riset Perikanan Budidaya Air Tawar dan Penyuluhan Perikanan. Jl. Sempur No. 1, Bogor 16129, Indonesia E-mail: wahyulia.cahyanti@gmail.com
} 


\section{PENDAHULUAN}

Ikan tambakan (Helostoma temminckii Cuvier, 1829) adalah salah satu jenis ikan perairan umum air tawar yang bersifat bentopelagik dan potadromus atau hidup di antara permukaan dan dasar perairan (Fishbase, 2019). Ikan ini memiliki distribusi dari Thailand hingga kepulauan di Indonesia bagian barat. Secara umum ikan tambakan mendiami habitat yang memiliki banyak tanaman air yang sangat dibutuhkan pada waktu musim pemijahan, berarus lambat, termasuk jenis omnivora, dan memiliki alat pernapasan tambahan untuk mengambil oksigen dari udara. Selain dikonsumsi, ikan tambakan juga dimanfaatkan sebagai ikan hias.

Populasi ikan tambakan di Indonesia tersebar di berbagai wilayah dan pulau, seperti Jawa, Sumatera, Sulawesi, dan Kalimantan. Produksi ikan tambakan didominasi hasil tangkapan alam dengan produksi tertinggi di daerah Kalimantan dan Sulawesi. Badan Pusat Statistik (BPS) Kabupaten Tabalong (2018), menyebutkan bahwa produksi tangkap ikan tambakan terus menurun dari 103 ton pada tahun 2009 menjadi 21,2 ton pada tahun 2016, sedangkan BPS Kabupaten Kotawaringin Timur (2016) mencatat produksi tangkap ikan tambakan tahun 2016 sebesar 60,36 ton. Menurut Gustiano et al. (2015), ikan tambakan merupakan salah satu dari 16 ikan air tawar spesifik lokal yang potensial untuk dikembangkan sebagai komoditas budidaya.

Keunggulan ikan tambakan yang utama adalah kemampuannya menoleransi rendahnya ketersediaan oksigen dalam air (Efriyeldi \& Pulungan, 1995). Di alam khususnya Kalimantan Barat, ikan tambakan menjadi target penangkapan untuk diambil telurnya. Benihnya banyak diperdagangkan untuk dijadikan ikan budidaya untuk memenuhi kebutuhan negara lain seperti Brunei dan Malaysia.

Beberapa penelitian pada ikan tambakan telah dilakukan terkait aspek pertumbuhan (Arifin et al., 2017a), genetik (Sundari et al., 2012; Ath-thar et al., 2014a; Arifin et al., 2017b), dan reproduksi (Efriyeldi \& Pulungan, 1995; Tafrani, 2012; Lisna, 2016). Namun demikian, studi terkait pengaruh domestikasi terhadap keragaan reproduksi pada ikan tambakan belum pernah dilakukan. Tujuan dari kegiatan penelitian adalah mengetahui posisi gonad, fekunditas, derajat pembuahan, dan derajat penetasan ikan tambakan generasi yang berbeda.

\section{BAHAN DAN METODE}

Kegiatan penelitian dilakukan di Instalasi Riset Plasma Nutfah Perikanan Air Tawar, Balai Riset Perikanan Air Tawar dan Penyuluhan Perikanan
(BRPBATPP), Bogor. Populasi induk yang digunakan adalah generasi awal yang merupakan populasi yang berasal dari Jawa Barat (G-0), generasi pertama (G-1), dan generasi kedua (G-2). Ikan tambakan dipelihara dan dimatangkan gonadnya di kolam selama tujuh bulan. Pemeliharaan induk dilakukan secara terpisah antara jantan dan betina dengan kepadatan 25 ekor/ $\mathrm{m}^{2}$. Selama pemeliharaan diberi pakan pelet komersial dengan kandungan protein $28 \% 30 \%$ dengan dosis pemberian harian $2 \% 4 \%$ dari biomassa, diberikan dua kali pada pukul 08.00 dan 16.00 WIB.

Ikan tambakan jantan dan betina yang siap mijah dapat dibedakan dengan memperhatikan ciri seksual primer dan sekunder. Ikan betina lubang genital berwarna kemerahan, bentuk tubuh membulat dan gemuk, bila diraba perutnya terasa lunak. Sedangkan ikan jantan lubang genitalnya berwarna pucat, bentuk tubuh lebih ramping, dan bila bagian perut ditekan akan mengeluarkan cairan sperma berwarna putih. Apabila ciri-ciri tersebut sudah terpenuhi maka bisa dilakukan pemijahan.

Pemijahan dilakukan dengan secara buatan, melalui penyuntikan ovaprim dengan dosis $0,6 \mathrm{~mL} / \mathrm{kg}$ induk betina dan $0,4 \mathrm{~mL} / \mathrm{kg}$ induk jantan. Penyuntikan dilakukan masing-masing sekali untuk setiap induk. Jumlah induk yang dipijahkan sebanyak tiga ekor betina pada G-0 dengan bobot rata-rata 138,3 \pm 5,44 g; lima ekor betina pada G-1 dengan bobot rata-rata $70,7 \pm 18,45 \mathrm{~g}$; dan G-2 dengan bobot rata-rata 55,8 $\pm 8,76 \mathrm{~g}$. Perbedaan ukuran induk antar generasi yang digunakan terjadi karena adanya perbedaan umur. Induk yang telah siap ovulasi dilakukan pengalinan (terjadi 8-12 jam setelah penyuntikan), kemudian telur dibuahi dengan mencampurkan dengan spermatozoa dan diaduk merata menggunakan bulu ayam. Selama proses pembuahan, dilakukan penambahan air bersih untuk aktivasi spermatozoa dan diaduk selama satu menit. Kemudian telur dibilas dengan air bersih. Telur yang telah dibilas diinkubasikan dan ditetaskan di dalam akuarium ukuran $60 \mathrm{~cm} \times 30 \mathrm{~cm} \times 20 \mathrm{~cm}$, dengan aerasi, sampai menetas ( \pm 18 jam setelah pembuahan).

Parameter yang diamati meliputi bobot saat memijah, posisi gonad, fekunditas telur, derajat pembuahan, dan derajat penetasan serta jumlah larva per gram bobot induk dari populasi induk asal (G0), populasi G1 dan G2.

Pengamatan posisi gonad dilakukan dengan cara pembedahan ikan. Ikan dibedah dari arah anus ke arah perut dan ke atas hingga terbuka keseluruhan salah satu sisi perutnya. Fekunditas dihitung berdasarkan metode gravimetrik, di mana diambil sampel telur sebanyak satu gram untuk kemudian dikonversi 
terhadap bobot keseluruhan telur yang diovulasikan. Derajat pembuahan telur diamati dengan menghitung jumlah telur yang dibuahi dengan yang digunakan dalam pembuahan. Pengamatannya dilakukan sejak pembuahan hingga jam keenam, dengan menghitung jumlah telur yang tidak terbuahi. Telur tidak terbuahi ditandai dengan warna telur yang berubah putih susu dan atau bakal embrio di dalam sel telur tampak pecah. Derajat penetasan merupakan persentase jumlah telur yang menetas dari jumlah telur yang dibuahi.

Data yang telah diperoleh kemudian dianalisis menggunakan ANOVA program MS. Excel 2016 dan SPSS 21.0 pada taraf kepercayaan 95\%untuk melihat pengaruh dari perlakuan yang diberikan. Jika ada perbedaan yang nyata antar perlakuan dilakukan uji lanjut dengan menggunakan metode BNT (Beda Nyata Terkecil).

\section{HASIL DAN BAHASAN}

Berdasarkan pengamatan pada G1 dan G2, awal matang gonad induk ikan tambakan G1 dicapai pada rata-rata umur tujuh bulan untuk induk betina dengan bobot rerata sebesar 28,5 $\pm 5,56 \mathrm{~g}$ dan panjang standar 9,6 $0,86 \mathrm{~cm}$. Pada induk jantan dicapai pada umur enam bulan dengan rerata bobot sebesar 18,3 $\pm 3,45 \mathrm{~g}$ dan panjang standar $8,2 \pm 0,64 \mathrm{~cm}$. Untuk induk $\mathrm{G} 2$ dengan rata-rata bobot $55,2 \pm 7,44 \mathrm{gram}$, memiliki bobot gonad sebesar 4,4 1,58 gram. Hasil penelitian menunjukkan nilai yang lebih kecil dibandingkan pada ikan tambakan yang berasal dari alam, di mana menurut Tafrani (2012), menyatakan ikan tambakan jantan pertama kali matang gonad pada ukuran 15,5 cm; sedangkan ikan betina pertama kali matang gonad pada ukuran $16,9 \mathrm{~cm}$.

Ikan tambakan tergolong heteroseksual yaitu spermatozoa dan sel telur masing-masing dihasilkan dari individu yang berbeda. Ovari dan testis ditemukan berkembang secara terpisah sejak pada fase benih dan kemudian setiap individu tetap berkelamin jantan maupun betina selama hidupnya (Lisna, 2016). Letak gonad ikan tambakan vertikal mengarah ke tulang belakang dan di bagian ujung melengkung ke arah depan dengan posisi gonad di belakang urogenital (Gambar 1). Warna gonad betina ikan tambakan yang matang gonad adalah kuning cerah, sedangkan jantan putih susu. Pengamatan letak, bentuk, dan warna go nad pada penelitian ini tidak berbeda baik pada induk populasi G-0, G-1, maupun G-2. Namun untuk gambar yang disajikan hanya ditampilkan untuk induk jantan dan betina G-1 saja. Warna gonad yang sama diduga karena pemberian pakan yang seragam antar populasi. Menurut Marlina (2018), bahwa perbedaan warna go nad betina dipengaruhi oleh jenis makanan serta tingkat kematangannya di mana semakin matang

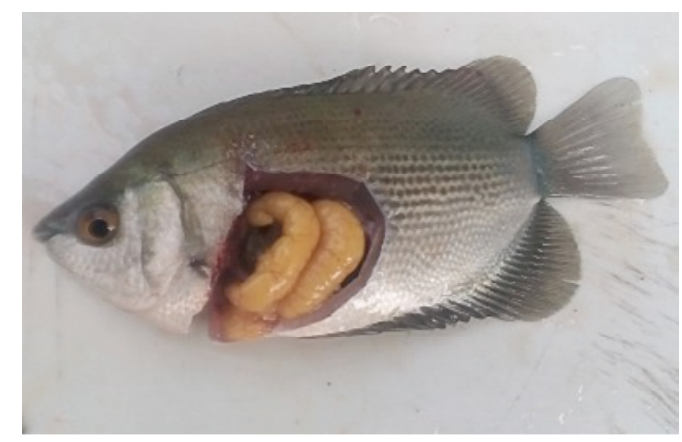

a

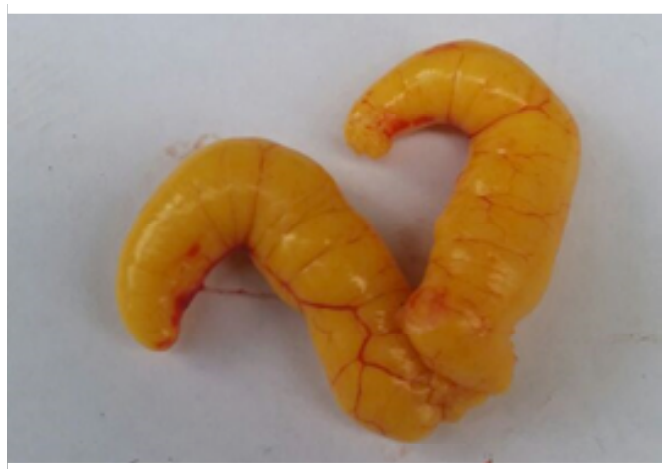

b

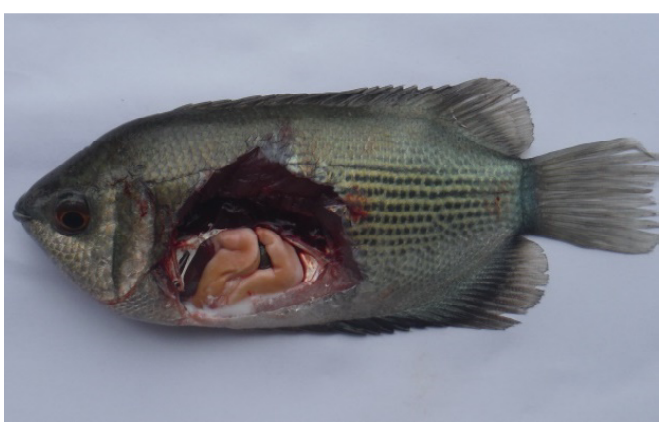

c

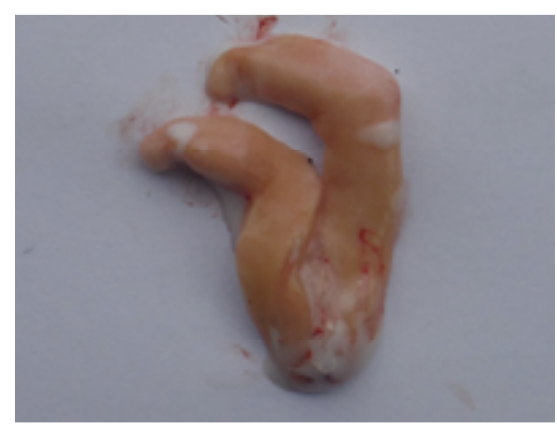

d

Gambar 1. Gonad ikan tambakan hasil pembedahan: (a) posisi ovari dalam tubuh ikan, (b) bentuk ovari, (c) posisi testis dalam tubuh, (d) bentuk testis.

Figure 1. Fish gonads appearance and position: (a) position of the ovaries in the body cavity of the fish, (b) ovary shape, (c) testicles position in the fish body cavity, (d) testicles shape. 
gonadnya semakin cerah warnanya. Sedangkan menurut Setyawati et al. (2015) bahwa tingkat kematanagan gonad betina berpengaruh terhadap warna.

Hasil pengamatan menunjukkan bahwa ukuran induk yang digunakan tidak memengaruhi keberhasilan pemijahan dan telur yang diperoleh. Hal tersebut terlihat pada ketiga populasi induk tambakan yang digunakan berhasil memijah semua. Perbedaan ketiga populasi, diperoleh pada data jumlah telur, derajat pembuahan, dan derajat penetasannya.

Rerata jumlah telur (Tabel 1) menunjukkan bahwa induk G-0 lebih banyak dibanding G-1 dan G-2 $(P<0,05)$. Persentase jumlah telur dibanding bobot tubuh induk tidak berbeda nyata $(P>0,05)$ antar generasi yang diamati. Berdasarkan jumlah telur yang dihasilkan, perbedaan ukuran induk yang digunakan dapat merupakan sumber perbedaan yang ada. Dugaan tersebut didukung oleh nilai persentase jumlah telur per bobot tubuh yang tidak berbeda nyata antar generasi. Dengan demikian perbedaan ukuran induk yang digunakan sangat memengaruhi perolehan telur yang dihasilkan oleh induk yang digunakan. Namun tidak memengaruhi rasio jumlah telur per bo bot induk. Variasi fekunditas pada ikan berhubungan dengan adaptasi ikan, serta terkontrolnya media pemeliharaan.
Hal tersebut menguatkan dugaan bahwa ikan tambakan baik G-0, G-1, maupun G-2 sudah sangat adaptif. Hal ini sejalan dengan penelitian Prakoso et al. (2020) yang menyatakan fekunditas induk ikan baung dari alam cenderung belum stabil jika dibandingkan dengan induk hasil domestikasi yang dipelihara dan diberi makan secara terkontrol.

Derajat pembuahan pada penelitian ini berkisar antara 70,6 \pm 16,05 sampai 92,9 $\pm 10,88 \%$ sedangkan derajat penetasan berkisar antara $51,3 \pm 16,64$ sampai $74,3 \pm 10,32 \%$ (Tabel 2). Data tersebut memperlihatkan adanya kecenderungan peningkatan dari G-0, G-1, dan tertinggi pada $\mathrm{G}-2$. Derajat pembuahan yang dihasilkan G-0, G-1, dan G-2 dan jumah larva yang diperoleh dari generasi yang berbeda menunjukkan nilai yang tidak berbeda nyata $(P>0,05)$. Derajat penetasan yang dihasilkan juga tidak berbeda nyata, namun derajat penetasan $\mathrm{G}-2$ lebih tinggi dibandingkan dua generasi sebelumnya. Lebih tingginya derajat penetasan $\mathrm{G}-2$ diduga akibat ikan yang sudah lebih adaptif dengan lingkungan pemeliharaan ex-situ. Nilai-nilai tersebut masih cukup tinggi, meskipun sedikit lebih rendah bila dinading penelitian Radona et al. (2014) yang menyatakan pemijahan ikan tambakan di BBIS Anjongan, Kalimantan Barat menghasilkan derajat pembuahan sebesar $82 \%$ dan derajat penetasan sebesar $80 \%$

Tabel 1. Jumlah induk, rata-rata bobot induk, jumlah telur, dan jumlah butir telur/bobot induk ikan tambakan yang dipijahkan

Table 1. Number of broodstock, average broodstock weight, number of eggs, and number of eggs/weight of spawned-broodstock

\begin{tabular}{ccccc}
\hline $\begin{array}{c}\text { Populasi } \\
\text { Population }\end{array}$ & $\begin{array}{c}\text { Jumlah induk (ekor) } \\
\text { Number of broodstock (fish) }\end{array}$ & $\begin{array}{c}\text { Bobot induk } \\
\text { Broodstock weight }(\mathbf{g})\end{array}$ & $\begin{array}{c}\text { Jumlah telur (butir) Jumlah butir telur/g bobot } \\
\text { Number of eggs }\end{array}$ & $\begin{array}{c}\text { Number of eggs/g weight } \\
\text { Numb }\end{array}$ \\
\hline G-0 & 3 & $138.3 \pm 5.44$ & $10,445 \pm 2,171.6^{\mathrm{a}}$ & $76.5 \pm 15.73^{\mathrm{a}}$ \\
G-1 & 5 & $70.7 \pm 18.45$ & $5,656 \pm 565.8^{\mathrm{b}}$ & $82.4 \pm 13.97^{\mathrm{a}}$ \\
G-2 & 5 & $55.8 \pm 8.76$ & $4,186 \pm 667.0^{\mathrm{c}}$ & $75.7 \pm 12.97^{\mathrm{a}}$ \\
\hline
\end{tabular}

Tabel 2. Rata-rata jumlah telur yang dibuahi, jumlah telur yang menetas, dan jumlah larva yang dihasilkan untuk setiap bobot ikan tambakan yang dipijahkan

Table 2. Average number of fertilized eggs, number of hatched eggs, and the number of larvae produced per unit weight of fish

\begin{tabular}{ccccccc}
\hline $\begin{array}{c}\text { Populasi } \\
\text { Population }\end{array}$ & $\begin{array}{c}\text { Jumlah telur yang } \\
\text { digunakan (butir) } \\
\text { Number of eggs } \\
\text { used (eggs) }\end{array}$ & $\begin{array}{c}\text { Telur dibuahi } \\
\text { (butir) } \\
\text { Fertilized eggs }\end{array}$ & $\begin{array}{c}\text { Persentase } \\
\text { telur dibuahi } \\
\text { Percentage of } \\
\text { fertilized eggs }\end{array}$ & $\begin{array}{c}\text { Jumlah telur } \\
\text { menetas (butir) } \\
\text { Hatched eggs }\end{array}$ & $\begin{array}{c}\text { Persentase } \\
\text { telur menetas } \\
\text { Percentage of } \\
\text { eggs hatch }\end{array}$ & $\begin{array}{c}\text { Jumlah larva/g } \\
\text { bobot induk }\end{array}$ \\
$\begin{array}{cccccc}\text { Number of larvae/g } \\
\text { broodstock weight }\end{array}$ \\
\hline G-0 & $10,445 \pm 2,171.6^{\mathrm{a}} \mathrm{a}^{\mathrm{a}}$ & $7,373 \pm 1,676.1$ & $70.6 \pm 16.05^{\mathrm{a}}$ & $5,354 \pm 1,738.1$ & $51.3 \pm 16.64^{\mathrm{a}}$ & $38.7 \pm 10.72^{\mathrm{a}}$ \\
G-1 & $5,656 \pm 565.8^{\mathrm{b}}$ & $4,338 \pm 343.5$ & $76.7 \pm 6.07^{\mathrm{a}}$ & $3,204 \pm 367.9$ & $56.6 \pm 6.50^{\mathrm{a}}$ & $45.3 \pm 5.20^{\mathrm{a}}$ \\
G-2 & $4,186 \pm 667.0^{\mathrm{c}}$ & $3,890 \pm 455.5$ & $92.9 \pm 10.88^{\mathrm{a}}$ & $3,110 \pm 432.2$ & $74.3 \pm 10.32^{\mathrm{a}}$ & $55.7 \pm 7.75^{\mathrm{a}}$ \\
\hline
\end{tabular}


Rerata jumlah larva/satuan bobot induk menunjukkan hasil tidak berbeda nyata $(P>0,05)$ antar generasi yang diamati, hal ini dapat dijadikan sebagai indikator kegiatan domestikasi yang dilakukan telah berhasil dalam fase reproduksi. Widyastuti et al. (2008) mendapatkan bahwa seleksi pertumbuhan yang dilakukan pada ikan nila juga tidak mendapatkan perbedaan reproduksi yang nyata pada ikan nila nonseleksi dan seleksi. Demikian pula dilaporkan oleh Ath-thar et al. (2014b) bahwa keragaan reproduksi beberapa ikan sepat dari Pulau Sumatera, Jawa, dan Kalimantan tidak berbeda nyata. Berdasarkan beberapa hasil di atas, dapat dikemukakan bahwa domestikasi, seleksi, dan keragaman populasi tidak berpengaruh terhadap keragaan reproduksi.

\section{KESIMPULAN}

Program domestikasi ikan tambakan tidak mempengaruhi karakter reproduksi ikan antar generasi. Keragaman karakter reproduksi antar generasi masih tinggi. Pembentukan generasi selanjutnya perlu dipertahankan, sehingga dapat digunakan sebagai ikan budidaya baru.

\section{UCAPAN TERIMA KASIH}

Terima kasih penulis sampaikan kepada Kepala BRPBATPP. Terima kasih juga kepada Deni Irawan, Heppy Aprilistianti, dan Fera Permata Putri selaku teknisi, serta semua pihak yang telah membantu dalam pelaksanaan penelitian.

\section{DAFTAR ACUAN}

Arifin, O.Z., Cahyanti, W., \& Prakoso, V.A. (2017a). Keragaan pertumbuhan ikan tambakan (Helostoma temminckii Cuvier, 1829) dengan kepadatan berbeda. Media Akuakultur, 14(2), 83-87.

Arifin, O.Z., Cahyanti, W., \& Kristanto, A.H. (2017b). Keragaman genetik tiga generasi ikan tambakan (Helostoma temminkii) dalam program domestikasi. Jurnal Riset Akuakultur, 12(4), 295305.

Ath-thar, M.H.F., Putriana, I., So elistyowati, D.T., \& Gustiano, R. (2014a). Performa genotip ikan tambakan Helostoma temminckii (Cuvier, 1829) populasi Sumatera, Jawa, dan Kalimantan dengan metode Random Amplified Polymorphic DNA (RAPD). Jurnal Sains Natural, 4(1), 68-75.

Ath-thar, M.H.F., Soelistyowati, D.T., \& Gustiano, R. (2014b). Performa reproduksi ikan sepat siam (Trichopodus pectoralis Regan 1910) asal
Sumatera, Jawa, dan Kalimantan. Jurnal Iktiologi Indonesia, 14(3), 201-210.

Badan Pusat Statistik Kabupaten Kotawaringin Timur. (2016). Produksi Ikan. Diakses pada 19 Januari 2021 jam 12.43 WIB, dari https:// kotimkab.bps.go.id/indicator/156/490/1/produksiikan.html.

Badan Pusat Statistik Kabupaten Tabalong. (2018). Produksi penangkapan ikan menurut jenis ikan tahun 2009-2016. Diakses pada 19 Januari 2021 jam 12.43 WIB, dari https://tabalongkab.bps.go.id/ statictable/2015/12/29/1405/produksipenangkapan-ikan-menurut-jenis-ikan-2009-2016.html.

Efriyeldi, \& Pulungan, C.P. (1995). Hubungan panjang berat dan fekunditas ikan tambakan (Helostoma temmincki) dari perairan sekitar Taratak Buluh. Pusat Penelitian Universitas Riau, Pekanbaru. 26 hIm (unpublish).

Fishbase. (2019). Helostoma temminckii Cuvier, 1829 kissing gourami. Diakses pada 20 M ei 2020, dari https://www.fishbase.de/summary/Helostomatemminckii.html.

Gustiano, R., Kusmini, I.I., \& Ath-thar, M.H.F. (2015). Mengenal sumber daya genetik ikan spesifik lokal air tawar Indonesia untuk pengembangan budidaya. IPB Press. $51 \mathrm{hlm}$.

Lisna. (2016). Aspek biologi reproduksi ikan tambakan (Helostoma temminckii) di perairan umum Kecamatan Kumpeh Ulu Kabupaten Muaro Jambi. Biospecies, 9(1), 15-22.

Marlina, I. (2018). Anatomi Dan Biometri Sistem Reproduksi Ikan Air Tawar Famili Cyprinidae Di Telaga Ngebel Ponorogo. Prosiding Seminar Nasional SIMBIOSIS III, hIm. 332-336.

Prakoso, V.A., Subagja, J., \& Arifin, O.Z. (2020). Keragaan reproduksi induk ikan baung alam dan hasil domestikasi serta pertumbuhan benih yang dihasilkannya. Media Akuakultur, 15(1), 1-7. http:/ /dx. doi.org/10.15578/ma.15.1.2020.1-7

Radona, D., Cahyanti, W., \& Kusmini, I.I. (2014). Teknologi pembenihan ikan tambakan (Helostoma temminckii) di Balai Budidaya Ikan Sentral Provinsi Kalimanatan Barat. Prosiding Forum Inovasi Teknologi Akuakultur, hlm. 885-891.

Setiawati, M., Putri, D., \& Jusadi, D. (2015). Survival and growth of catfish Pangasionodon sp. larvae fed on vitamin C-enriched Artemia. Jurnal Akuakultur Indonesia, 12(2), 136-143. 
Sundari, S., Iskandariyah, Huwoyon, G.H., Kusmini, I.I., \& Gustiano, R. (2012). Keragaman genetik 3 populasi ikan tambakan (Helostoma temminckii) asal Sumatra, Jawa dan Kalimantan menggunakan metode RAPD. Prosiding Forum Inovasi Teknologi Akuakultur, hlm. 1109-1114

Tafrani. (2012). Makanan dan reproduksi ikan tambakan (Helostoma temminckii, C.V 1829) di perairan Lubuk Lampam, Sungai Lempuing,
Sumatera Selatan. Skripsi. Budidaya Perairan. Fakultas Perikanan dan IImu Kelautan. Institut Pertanian Bogor. Bogor, $49 \mathrm{hlm}$.

Widyastuti, Y.R., Subagja, J., \& Gustiano, R. (2008). Reproduksi ikan nila (Oreocltromis niloticus) seleksi dan non-seleksi dengan pemijahan buatan: karakter induk, telur, embrio dan benih. Jurnal Iktiologi Indonesia, 8(1), 17-20. 